\title{
CONTRIBUTORS TO THIS VOLUME
}

Hannes Adomeit

Stiftung Wissenschaft und Politik

David E. Albright

Air War College

Vernon V. Aspaturian

Pennsylvania State University

Seweryn Bialer

Columbia University

Lester R. Brown

Worldwatch Institute

Zbigniew Brzezinski

Columbia University

Center for Defense Information

Washington, D.C.

Stephen F. Cohen

Princeton University

Joseph J. Collins

U.S. Military Academy

Timothy J. Colton

University of Toronto

Alexander Dallin

Stanford University

Karen Dawisha

Princeton University

Charles Gati

Union College

Harry Gelman

The Rand Corporation

Roy Godson

Georgetown University

Rose E. Gottemoeller

The Rand Corporation

Franklyn Griffiths

University of Toronto

Thane Gustafson

Georgetown University

John P. Hardt

U.S. Library of Congress

Dale R. Herspring

U.S. Department of State
Erik P. Hoffmann

State University of New York

at Albany

David Holloway

University of Edinburgh

Jerry F. Hough

Duke University

William G. Hyland

Georgetown University

Stephen S. Kaplan

The Brookings Institution

George F. Kennan

Institute for Advanced Study

Robert W. Kitrinos

U.S. Department of Defense

Robbin F. Laird

Institute for Defense Analyses

F. Stephen Larrabee

Institute for East-West Security Studies

Robert Legvold

Columbia University

Marian Leighton

U.S. Department of Defense

William H. Luers

U.S. Department of State

Edward N. Luttwak

Georgetown University

Paul Marer

Indiana University

Richard Pipes

Harvard University

Alvin Z. Rubinstein

University of Pennsylvania

Marshall D. Shulman

Columbia University

George P. Shultz

U.S. Department of State

Richard H. Shultz

Tufts University 
Dimitri K. Simes Carnegie Endowment for International Peace

Helmut Sonnenfeldt The Brookings Institution

Angela E. Stent Georgetown University John J. Stephan University of Hawaii at Manoa Kate S. Tomlinson U.S. Library of Congress
Adam B. Ulam Harvard University Elizabeth Kridl Valkenier Columbia University Allen S. Whiting University of Arizona

Donald S. Zagoria Hunter College, City University of New York

William Zimmerman University of Michigan 